Diabetologia $7,68-72(1971)$

(C) by Springer-Verlag 1971

\title{
The Role of the Exocrine Pancreas in the Stimulation of Insulin Secretion by Intestinal Hormones*
}

\author{
II. Insulin Responses to Secretin and Pancreozymin in Experimentally-Induced Pancreatic Exocrine Insufficiency
}

\author{
R. Goberna**, R.D. Fussgänger, S. Raptis, M. Telib and E.F. Pfeiffer****
}

Department of Endocrinology and Metabolism, Center of Internal Medicine and Pediatrics, University of Ulm, Germany Received: October 12, 1970, accepted: December 18, 1970

Summary. A comparison was made of the effects of the intestinal hormones secretin and pancreozymin on insulin secretion in non-diabetic rats with experimentically induced exocrine pancreatic insufficiency and in control animals. The rats with exocrine pancreatic insufficiency exhibited normal disappearence of glucose and secretion of insulin. In rats with exocrine pancreatic insufficiency secretin did not lead to any increase in insulin secretion in contrast to its effect in the controls. In rats with exocrine pancreatic insufficiency pancreozymin evoked secretion of insulin to the same extent as in the normal animals. - From these results it is inferred that the effect of secretion upon the $\beta$-cells of the rat is dependent upon the presence of intact exocrine pancreatic tissue. However, pancreozymin and glucose exert their effects upon the $\beta$-cells directly without the involvement of the exocrine portion of the pancreas. All of these findings made under conditions in vivo are in perfect accord with studies made on isolated islets of rats subjected to the same stimuli in the preparation in vitro.

Le rôle du pancréas exocrine dans la stimulation de la sécrétion d'insuline par des hormones intestinales. - II. Réponse de l'insuline à la sécrétine et à la pancréozymine dans l'insuffisance pancréatique exocrine expérimentale

Résumé. L'influence de la sécrétine et de la pancréozymine intravenieuses sur la sécrétion d'insuline a été étudiée chez des rats ayant une insuffisance pancréatique exocrine. La sécrétine et la pancréozymine ont causé une sécrétion d'insuline significative chez des rats normaux. L'effet de ces hormones a été différent chez les animaux ayant une insuffisance pancréatique exocrine; alors que la pancréozymine causait une sécrétion d'insuline chez ces animaux, la sécrétine n'en causait aucune. Le glucose intravenieux, quant à lui, produisait une augmentation d'insuline du sang même chez les rats ayant une insuffisance pancréatique exocrine. Il semble que seule l'action de la sécrétine sur la sécrétion d'insuline soit liée au pancréas exocrine intact. Par contre la pancréozymine stimule la sécrétion d'insuline même dans le cas d'une insuffisance pancréatique exocrine. Ces résultats in vivo sont indentiques à ceux obtenus avec les ilôts isolés du pancréas des rats.

Die Rolle des exokrinen Pankreas bei der Stimulation der Insulinsekretion durch intestinale Hormone. - II. InsulinAusschüttung nach Sekretin und Pankreozymin bei experimentell ausgelöster Insuffizienz des exokrinen Pankreas

Zusammenfassung. Bei Ratten mit exokriner Pankreasinsuffizionz, erzeugt durch vollständige Ligatur sämtlicher Pankreasausführungsgänge mit anschließender fettiger Degeneration, wurde der Einfluß von Sekretin und Pankreozymin i.v. auf das immunologisch meßbare Insulin geprüft. Bei normalen Ratten führten Sekretin und Pankreozymin zu einer signifikanten Insulinausschüttung. Bei Tieren mit Pankreasinsuffizienz war ein unterschiedlicher Effekt beider Hormone nachzuweisen. Während Pankreozymin auch bei pancreasinsuffizierten Tieren einen deutlichen Anstieg der Insulinselkretion bewirkt, fehlt nach Sekretin die reaktive Insulinsecretion. I.v. Glucose bewirkte hingegen auch bei den pankreasinsuffizienten Ratten einen Insulinanstieg in Plasma. Offensichtlich ist lediglich die insulinstimulierende Wirkung von Sekretin an ein intaktes exokrines Pankreas gebunden, während Pankreozymin auch bei Pankreasinsuffizienz das Inselsystem zur Insulinabgabe veranlaßt. Diese Befunde in vivo sind übereinstimmend mit den Versuchen an isolierten Inseln der Ratten.

Key-words: Glucose, duct ligation, IMI, secretin, pancreozymin, K-value.
In contrast to experiments in vivo and slices of pancreatic tissue (cf. Pfeiffer and Raptis (1968), Lazarus, Voyles, Devrim, Tanese and Recant (1968), Pfeiffer (1969), isolated islets of rat pancreas do not respond to stimulation of insulin secretion by secretin and gastrin, whereas pancreozymin (under all conditions examined) and glucagon (in presence of glucose solely) will promote insulin release (Hinz, Katsilambros,

* Part of this paper was presented on the occasion of the 5 th annual meeting of the European Association for the study of diabetes, Montpellier 1969.

** Fellow of Alexander von Humboldt Stiftung.

*** Supported by Deutsche Forschungsgemeinschaft, Bad Godesberg, Germany, (Pf 38/24).
Schweizer, Raptis and Pfeiffer (1970)). Only with respect to glueagon, and to certain concentrations of glucose added to the medium, did our findings correspond to those obtained by Buchanan, Vance and Williams (1969), who also employed isolated islets, whereas the other intestinal hormones, in the hands of Buchanan et al., failed to cause insulin liberations. Although our result (Hinz et al. (1970)) confirmed the original observations of Guidoux-Grassi and Felber (1968), Vannotti, Hadjikhani, Fasel, Guidoux and Felber (1969) with regard to secretin-induced insulin release, the capacities of pancreozymin and glucagon to act in the absence of exocrine pancreatic tissue upon the Langerhans islets in vitro initiated similar 
studies under conditions in vivo. Heretofore, it was thought that only secretin lacked the capacity of stimulating insulin release in the setting of pancreatic insufficiency (Guidoux-Grassi and Felber (1968)). Therefore the action of pancreozymin in this condition remained to be determined. In the studies to be reported, insufficiency of the exocrine pancreatic tissue was produced surgically by ligation of the pancreatic ducts. All animals investigated were subjected to glucose tolerance tests. Secretin and pancreozymin were selected as representatives of the gastrointestinal hormones that either do not effect insulin releases from isolated islets under any conditions, or which do promote insulin secretion of the isolated islets in all situations examined.

\section{Material and Methods}

Experimental animals. 107 male Wistar-Albino rats of an inbred strain, 70-80 days of age and weighing $200-250 \mathrm{~g}$, kindly provided by Thomae Corp., Biberach an der Riss, were used throughout the experiment.

Feeding procedure. Rats are known to eat at night in an inconstant manner. In order to establish a controlled fasting state defined by relatively small standard deviation of basal glucose and immunologically measurable insulin (IMI) the following feeding schedule was established: first, the rats were fasted for $12 \mathrm{~h}$, then allowed to eat for one hour, and then deprived of food for another $7 \mathrm{~h}$. Standard laboratory pellet chow (Altromin-R 15) was used.

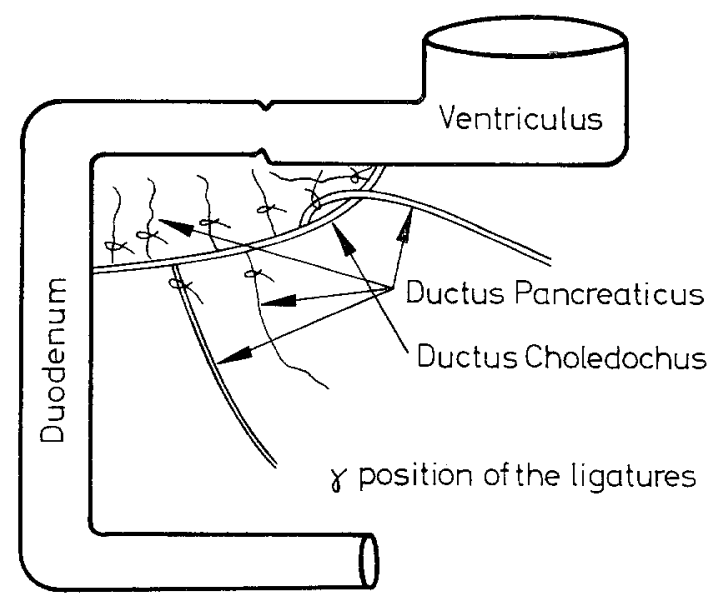

Fig. 1. Situation of ligatures in the rats

Duct ligation. In 48 animals exocrine pancreatic insufficiency was instituted by ligation of the pancreatic ducts after anaesthesia with Nembutal ${ }^{\circledR}$ (40 mg/kg). In Fig. 1 the anatomical position of the ligatures is indicated. 59 rats served as unoperated controls and 52 rats as sham-operated. 3-4 weeks later the animals were injected with secretin and pancreozymin.
Glucose tolerance test. Two groups of animals were used for a glucose tolerance test $(0.5 \mathrm{~g} / \mathrm{kg}, 10 \%)$ intravenously. Glucose disappearance and IMI were measured in the blood of the jugular vein by collecting samples through a cannula remaining in place throughout the experiment.

The determination of blood glucose was performed according to the method of Stork and Schmidt (1968) using hexokinase and G6P-Dehydrogenase.

The immunologically measurable insulin was measured following Melani, Ditschuneit, Bartelt, Friedrich and Pfeiffer (1965). Glucose assimilation (K-value) was calculated according to Conard (1955).

Secretin and pancreozymin tests. Secretin (Vitrum, Stockholm, Lot. Nr. 16851) and pancreozymin (Lot. Nr. 26921) were injected intravenously in doses of $10 \mathrm{U} / \mathrm{kg}$ body weight. Directly before as well as 5 and 15 min following the injection of secretin and pancreozymin, blood was secured for determinations of glucose and immunologically measurable insulin (IMI). 15 min after injection of secretin or pancreozymin each rat was given glucose $0.5 \mathrm{~g} / \mathrm{kg}$ intravenously. $5 \mathrm{~min}$ later blood was provided again for determination of glucose and IMI. All experiments were performed $15 \mathrm{~min}$ following Nembutal ${ }^{\circledR}$ anaesthesia $(40 \mathrm{mg} / \mathrm{kg}$ ).

Statistical Evaluation. The significance of the results was assesed by SEM and the Student-test.

\section{Results}

There was no difference in body weight between experimental and control animals, although several findings were considered as indicating exocrine pancreatic insufficiency in the experimental animals:

1. The weights of the stools of the experimental animals were increased to $27 \pm 2$ g/day (SEM), whereas the stools in normal animals weighed $12 \pm$ $2 \mathrm{~g} /$ day (three weeks following duct ligation).

2. All specimens of pancreatic tissue of experimental animals were macroscopically smaller and paler than those of the controls.

3 . The weight of the ligated pancreatic glands averaged $60 \pm 6 \mathrm{mg} / 100 \mathrm{~g}$ body weight, the weight in the normal animals amounted to $298 \pm 11 \mathrm{mg} / 100 \mathrm{~g}$.

4. Microscopically, the exocrine pancreatic tissue was markedly diminished and replaced by fat tissue in comparison with the pancreas of intact animals (Fig. 2). However, the Langerhans islets of the ligated rats seemed unaffected.

Glucose disappearance and insulin release following administration of glucose intravenously. Table 1 indicates the insulin response to glucose in both the rats with ligated pancreatic ducts and in the controls. The glucose assimilation coefficients (K-values) and the insulin release were not different in the two groups of animals. 
Effects of secretin. The administration of secretin to normal animals did not produce appreciable changes in the blood glucose curves. In animals with pancreatic duct ligation, secretin evoked a modest but significant rise in blood sugar $(p<0.005)$ (Fig. 3A). The IMT following secretin rose in the control animals from $28 \pm 2 \mu \mathrm{U} / \mathrm{ml}$ to $60 \pm 4 \mu \mathrm{U} / \mathrm{ml}$ within $5 \mathrm{~min}$.

On the other hand, the experimental animals (pancreatic duct ligation) did not exhibit elevations in the IMI concentrations in the serum following secretin injection (Fig. 3B). 15 min following administration of secretin, glucose $(0.5 \mathrm{~g} / \mathrm{kg})$ was given intravenously to the same animals. The IMI-values measured after 5 min showed difference between the normal $(108 \pm$ $7 \mu \mathrm{U} / \mathrm{ml})$ and the experimental animals $(102 \pm 8 \mu \overline{\mathrm{U} /}$ ml) (Fig. 3).

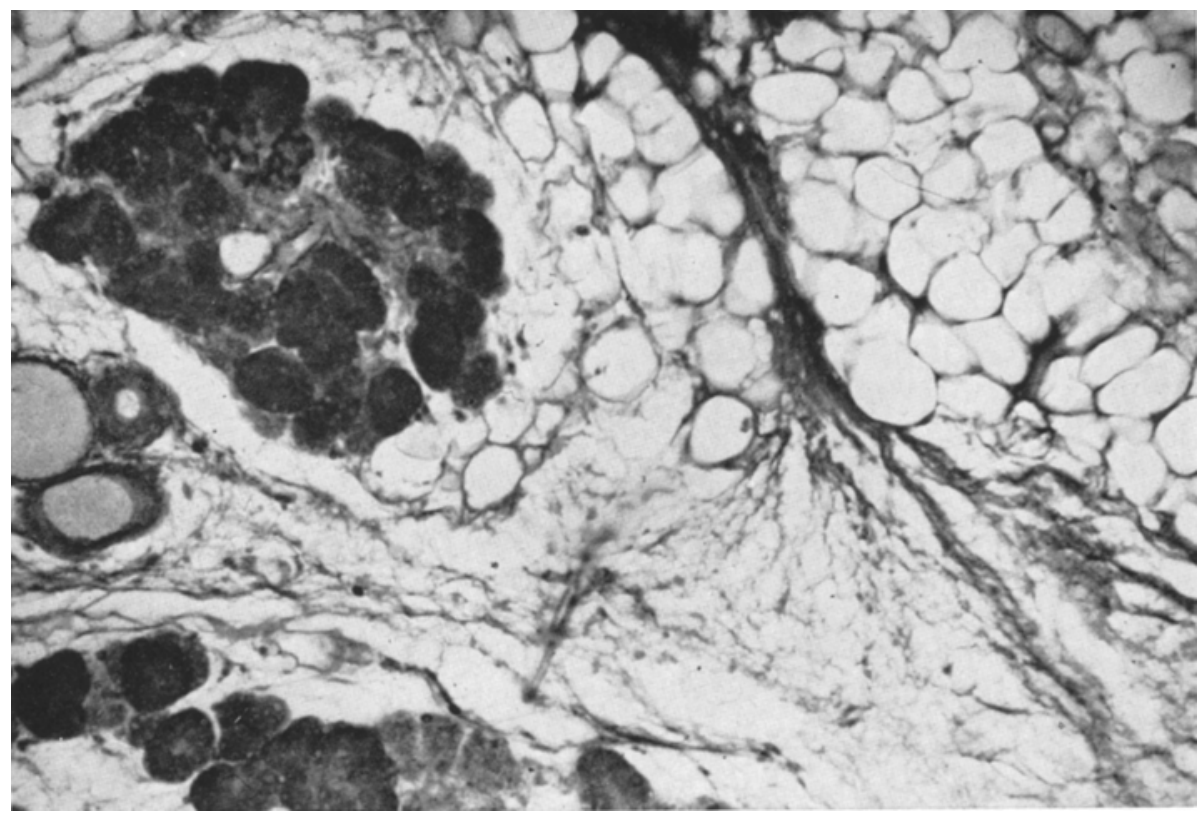

Fig. 2. Fatty degeneration and fibrosis of the excretory pancreatic tissue of rats following duct ligation
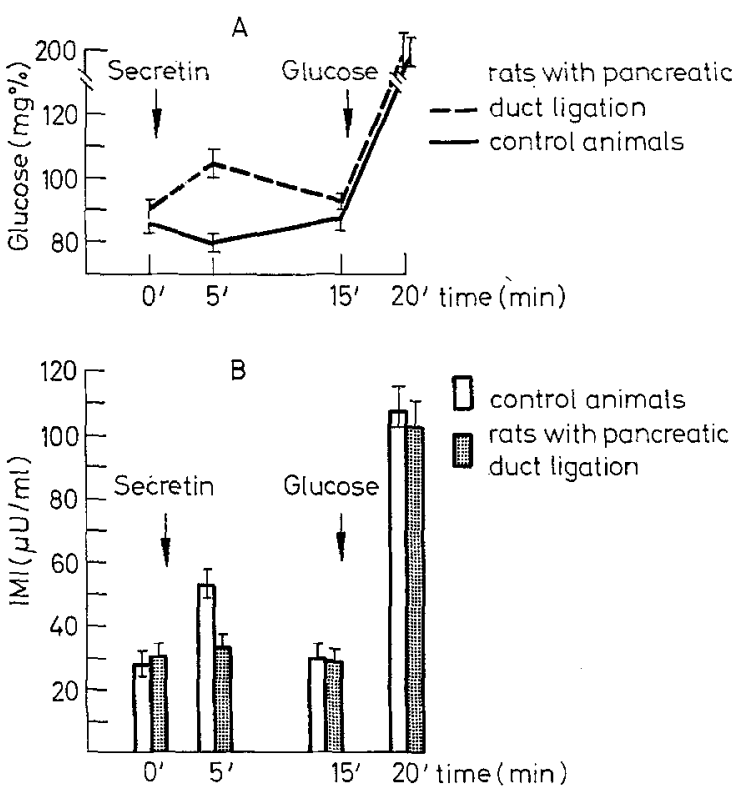

Fig. 3. Effect of i.v. injection of secretin and glucose on blood glucose and insulin release in rats with ligated pancreatic ducts $(n=18)$ and in control animals $(n=19)$. Means \pm SEM
Table 1. Glucose disappearence $\left(K_{\mathrm{G}}\right)$ and insulin release following $0.5 \mathrm{~g} / \mathrm{kg}$ glucose intravenously in rats with ligated pancreatic ducts and controls. Means $\pm S E M$

\begin{tabular}{lcccc}
\hline & $K_{\mathrm{G}}$ & \multicolumn{3}{c}{$\mathrm{IMI}(\mu \mathrm{U} / \mathrm{ml})$} \\
& & $0(\mathrm{~min})$ & $5(\mathrm{~min})$ & $30(\mathrm{~min})$ \\
\hline $\begin{array}{l}\text { Control rats }(n=20) \\
\begin{array}{l}\text { Rats with ligated } \\
\text { pancreatic duct } \\
(n=20)\end{array}\end{array}$ & 2.14 & $22 \pm 2$ & $135 \pm 6$ & $72 \pm 4$ \\
\hline
\end{tabular}

Effects of pancreozymin. However, the intravenous injection of pancreozymin resulted in a slight significant fall in blood sugar $(p<0.01)$ in the experimental animals as well as in the controls (Fig. 4A). The IMI rose markedly 5 min after injection of pancreozymin in both groups of animals (Fig. 4B) in contrast to the IMI curves measured in the secretin injected rats. In the normal animals the values were $30 \pm 3 \mu \mathrm{U} / \mathrm{ml}$ increasing to a value of $98 \pm 8 \mu \mathrm{U} / \mathrm{ml}$. In the experimental animals the values were $28 \pm 4$ rising to $118 \pm 13$. This increase in plasma-IMI after injection of pancreozymin is comparable with that obtained in either group following administration of glucose 
where the IMI values in the control rats rose to $105+$ $7 \mu \mathrm{U} / \mathrm{ml}$ and in the experimental animals to $115 \pm$ $14 \mu \mathrm{U} / \mathrm{ml}$ (Fig. 4).

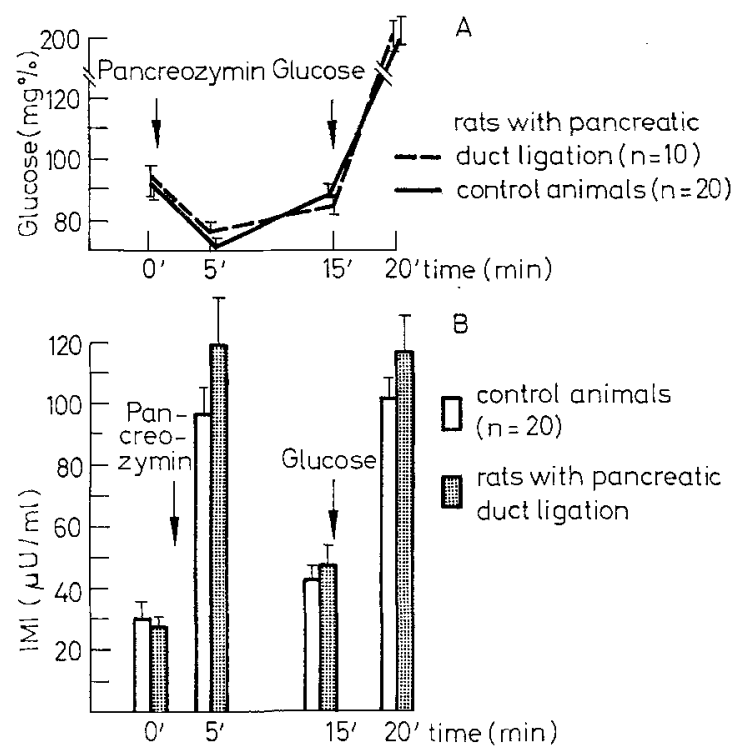

Fig. 4. Effect of i.v. injection of pancreozymin and glucose on blood glucose and insulin release in rats with ligated pancreatic ducts $(n=10)$ and in control animals $(n=20)$. Means \pm SEM

\section{Discussion}

In rats with atrophy of the exocrine pancreatic tissue subsequent to ligation of the pancreatic ducts the insulin response to secretin, pancreozymin and glucose injected intravenously was evaluated. In the animals with pancreatic insufficiency the insulin response to secretin was completely abolished whereas pancreozymin and glucose still elicited normal insulin release. Likewise, glucose assimilation ( $K$-value) was in the normal range, i.e. none of the experimental animals were diabetic. These findings are in accord with our observations made on isolated islets (Pfeiffer (1969), Hinz et al. (1970)). Again, they confirm the ineffectiveness of secretin in promoting insulin release from slices of pancreas deprived of functionally active exocrine tissue (Guidoux-Grassi and Felber (1968), Vanotti et al. (1969)). Moreover, and perhaps of greater importance, they demonstrate the independence of the insulin-releasing capacities of pancreozymin in the absence of exocrine pancreatic tissue, thus confirming again the findings from the preparation in vitro (Pfeiffer (1969), Hinz et al. (1970)). The rat islets separated artifically from the exocrine cells and the Langerhans islets left in situ, but surrounded by inactive exocrine tissue, behave identically. They do not respond to secretin under any conditions, and they do respond to pancreozymin with insulin secretion under all conditions, i.e. with and without the presence of glucose. Finally, the insulin response to glucose already dem- onstrated in the preparations in vitro of the incubated and the perfused isolated islets were also normal in vivo in animals suffering from experimental pancreatic exocrine insufficiency.

In essence, these results suggest that in rats secretin has its action upon the $\beta$-cells of the pancreas in part via the exocrine tissue. The mechanism of this effect remains unknown although several possibilities can be suggested. Morphological data indicate that vascular integrity of the exocrine portion of the gland may be necessary for the effectiveness of secretin. Falkmer, Edström Bosquist and Hassler (1969) have demonstrated essential differences of vessels in microangiographic studies. Moreover, the importance of the lymphatic drainage of the pancreas in the releasing capacity of secretin should be noted. Secretin diminishes lymphatic flow in normal individuals (unpublished results). It might be possible that insulin increase following secretin is a consequence of a shunt of lymphatically transported interstitial hormone into blood vessels. On the other hand, secretin might have glucagon-stimulating activity as has been shown for pancreozymin in vivo in dogs (Unger et al. 1967) as well in vitro in rats (Fußgänger et al. 1969). Activation of gluconeogenesis may result from the known lipolytic action of secretin (Raptis et al. 1969).

It remains to be established whether gastrin and glucagon will show similar differences as secretin and pancreozymin in experimental insufficiency of the exocrine pancreas. These studies are in progress.

\section{References}

Buchanan, K.D., Vance, J.E., Williams, R.H.: Insulin and glucagon release from isolated islets of Langerhans. Effect of enteric factors. Diabetes 18, 381-386 (1969).

Conard, V.: Mesure de l'assimilation du glucose: base théorique et applications cliniques. Acta gastro-ent. belg. 18, 803-845 (1955).

Fußgänger, R.D., Straub, K., Goberna, R., Jaros, P., Schröder, K.E., Raptis, S., Pfeiffer, E.F.: Primary secretion of insulin and secondary release of glucagon from the isolated perfused rat pancreas following stimulation with pancreozymin. Horm. Metab. Res. 1, 224227 (1969).

Guidoux-Grassi, L., Felber, J.P.: Effect of secretin on insulin release by rat pancreas. Diabetologia 4, 386386 (1968).

Hinz, M., Katsilambros, N., Schweizer, B., Raptis, S., Pfeiffer, E.F.: The role of the exocrine pancreas in the stimulation of insulin secretion by the intestinal hormones. I. Effect of pancreozymin, secretin, gastrin, penta-peptide and of glucagon upon insulin secretion of isolated islets of rat pancreas. Diabetologia $7,1-5$ (1971).

Lazarus, N.R., Voyles, N.R., Devrim, S., Tanese, T., Recant, L.: Extra-gastrointestinal effects of secretin, gastrin and pancreozymin. Lancet $1968 \mathrm{II}, 248-250$.

Melani, F., Ditschuneit, H., Bartelt, K. M., Friedrich, H., Pfeiffer, E.F.: Ưber dio radioimmunologische Bestimmung von Insulin im Blut. Klin. Wschr. 43, 1000-1007 (1965).

Pfeiffer, E.F.: Intestinale Hormone und Insulinsekretion Verh. dtsch. Ges. inn. Med. 75, 296-315 (1969). 
- Raptis, S.: Intestinale Hormone und Insulinsekretion. Klin. Wschr. 46, 337-342 (1968).

Raptis, S., Faulhaber, J.D., Schröder, K.E.: The effect of intestinal hormones upon lipolysis of isolated human fat cells. Horm. Metab. Res. 1, 249-250 (1969).

Stork, H., Schmidt, F.H. : Mitteilung über eine encymatische Schnellmethode zur Bestimmung des Blutzuckers in $5 \mu$ l Capillarblut ohne Enteiweißung und ohne Zentrifugation. Klin. Wschr, 46, 789-790 (1968).

Unger, R.H., Ketterer, H., Dupre, J., Eisentraut, A.M. The effects of secretin, pancreozymin and gastrin on insulin and glucagon secretion in anesthetized dogs. J. clin. Invest. 46, 630-645 (1967).
Vannotti, A., Hadjikhani, H., Fasel, J., Guidoux, L., Felber, J.P.: The endocrine function of the intestinal mucosa. Amer. J. Proctol. 20, 68-71 (1969).

Dr. R. Goberna

Dept. of Endocrinology and Metabolism Center of Internal Medicine and

Paediatries

University of Ulm

BRD-7900 Ulm/Donau

Steinhövelstr. 9

Deutschland 